\title{
ANALISIS POTENSI PASAR CIPLUKAN TERHADAP PEREKONOMIAN MASYARAKAT DI DESA WISATA LEMBAH DONGDE MOJOGEDANG KARANGANYAR
}

Pontianus Kuswiyata ${ }^{1}$, dan Erna Wigati ${ }^{2}$

${ }^{1,2}$ Akademi Pariwisata Mandala Bhakti, Surakarta, Indonesia, Email: atta cos@yahoo.com

\begin{abstract}
ABSTRAK
Histori Artikel

Submitted:

30 September 2022

Reviewed:

16 Oktober 2022

Accepted:

05 November 2022

Published:

15 Mei 2022

Artikel ini untuk mengetahui asal usul serta event yang pernah diselenggarakan di pasar ciplukan dan pengaruh pasar ciplukan terhadap perekonomian masyarakat desa wisata lembah dongde. Metode yang digunakan adalah metode kualitatif dengan melakukan pengamatan, observasi dan interview terhadap pengurus Pokdarwis dengan tujuan untuk mengetahui potensi pasar ciplukan terhadap perekonomian masyarakat Desa Wisata Lembah Dongde. Hasil menunjukan bahwa Pasar Ciplukan terbentuk dari usulan salah satu pendamping Perguruan Tinggi saat melakukan pendampingan dengan memanfaatkan pekarangan. Dari beberapa potensi yang dikembangkan di pasar ciplukan membawa pengaruh yang luar biasa dalam perekonomian masyarakat di desa wisata tersebut. Masyarakat mendapatkan tambahan pemasukan serta desapun mendapatkan income dari penghasilan pasar ciplukan.

Kata Kunci: Potensi $^{1}$, Pasar Ciplukan ${ }^{2}$, Perekonomian ${ }^{3}$, Masyarakat $^{4}$, Desa Wisata ${ }^{5}$

\section{ANALYSIS OF THE POTENTIAL OF THE CIPLUKAN MARKET ON THE COMMUNITY ECONOMY IN THE TOURISM VILLAGE OF THE DONGDE VALLEY OF MOJOGEDANG KARANGANYAR}

\begin{abstract}
This study aims to determine the origin and events that have been held in the ciplukan market and the influence of the ciplukan market on the economy of the Dongde Valley tourism village community. The Method used by the reseach is a qualitative method by conducting observations and interviews with Pokdarwis management with the aim of knowing the potential of the ciplukan market for the economy of the Dongde Valley Tourism Village community. The result of the research is the Ciplukan Market was formed from the proposal of one of the college companions when providing assistance by utilizing an unorganized yard. Ciplukan Market experienced several activities or events such as the launching of the Tourism village, the judging of the Tourism Village, The Telo Festival and The Goat Festival. Of the several potentials developed in the Ciplukan Market, it has had a tremendous influence on the economy of the Dongde Valley tourism village community. The community gets additional income the village also gets income from the ciplukan market income.
\end{abstract}

Keywords: Potential ${ }^{1}$, Ciplukan Market ${ }^{2}$, Economy $^{3}$, Community $^{4}$, Tourism Village $^{5}$

\section{PENDAHULUAN}

Pesatnya perkembangan industri pariwisata Pada tahun 2016 World Travel \& Tourism Council menyebutkan bahwa sektor pariwisata telah memiliki pertumbuhan yang cukup pesat, yakni sekitar 4,4\% per tahunnya dan menyumbang sekitar 10\% GDP dunia (Reza, 2018) menyebabkan banyak negara di 
dunia yang menganggap pariwisata sebagai satu di antara aspek terpenting dan integral dari strategi pengembangan Negara. Banyak literatur kepariwisataan yang memberikan ulasan bahwa sektor pariwisata memberikan keuntungan ekonomi terhadap negara yang bersangkutan. Keuntungan-keuntungan ini biasanya diperoleh dari pendapatan nilai tukar mata uang asing, pendapatan pemerintah, stimulasi pengembangan regional, dan penciptaan tenaga kerja serta peningkatan pendapatannya.

Menurut Salah Wahab (Salah, 2003) Industri pariwisata adalah salah satu jenis industri baru yang mampu mempercepat pertumbuhan-pertumbuhan ekonomi dan penyedian lapangan kerja, Peningkatan penghasilan, standart hidup serta menstimulasi sektor-sektor produktif lainnya. Selanjutnya, sebagai sektor kompleks, pariwisata juga merealisasi industri klasik seperti industri kerajinan tangan, cinderamata, tour, pasar, penginapan dan transportasi. Disebut sebagai suatu industri karena aktivitas rekreasi (pariwisata) tersebut secara ekonomi telah menciptakan permintaan yang memerlukan pasar bagi produk barang dan jasa pelayanan yang dihasilkan oleh suatu perusahaan yang masing-masing terpisah sama sekali, namun saling melengkapi. Di Kabupaten karanganyar memiliki banyak pedesaan yang memiliki banyak potensi yang bisa dikembangkan.

Kabupaten Karanganyar memiliki wisata alam dan juga banyak desa wisata, salah satunya adalah Desa Wisata Lembah Dongde, yang terletak di Dusun Mlilir, RT 01 RW 03 Desa Gentungan, Kecamatan Mojogedang, Kabupaten Karanganyar. Desa Wisata Lembah Dongde ini menyuguhkan keadaan alamnya yang masih asri, selain menyuguhkan alamnya, Desa Wisata Lembah Dongde juga mempunyai banyak destinasi wisata seperti tol sawah (tolsa) yaitu tol sawah sepanjang 217 meter yang mempunyai view persawahan dan Gunung Lawu, di samping tol sawah (tolsa) juga terdapat menara tani untuk berselfi ria, selain tol sawah (tolsa) juga ada paket edukasi, tubing sepanjang 625 meter dan petik jeruk calivornia.

Desa Wisata Lembah Dongde juga memiliki bermacam-macam edukasi yang tidak kalah menarik, seperti: omah tiwul, omah brabuk, omah jadah, edukasi kambing, edukasi jamur, kerajinan anyam bambu, kerajinan talipet, dan pertanian. Selain destinasi dan tour-nya, Desa Wisata Lembah Dongde juga menyediakan penginapan (homestay), serta juga adanya pemberdayaan masyarakat dengan di dirikannya pasar, yang di beri nama Pasar Ciplukan. Penjual yang berjualan di pasar Ciplukan adalah warga masyarakat desa wisata lembah dongde yang menjual berbagai macam makanan tempo doloe (jadul). Pokdarwis membagi berdasarkan dasawisma yang ada dan penjual yang ingin berjualan secara mandiri. Wisatawan yang sudah berkunjung di Desa Wisata Lembah Dongde untuk menikmati suasana desa, mengunjungi edukasi-edukasi yang ada, berbelanja di Pasar Ciplukan maupun menginap di homestay, yang menjadikan perekonomian masyarakat meningkat secara drastis. Dengan adanya strategi dan kesadaran masyarakat terhadap pengelolaan setiap potensi-potensi yang ada, nantinya Desa Wisata Lembah Dongde diharapkan menjadi lebih Desa Wisata yang lebih berkembang. Pada artikel ini peneliti ingin menyoroti Analisa Potensi Pasar Ciplukan Terhadap Perekonomian Masyarakat Di Desa Wisata Lembah Dongde.

\section{LITERATUR REVIEW}

Potensi Pasar menurut Kotler (1997) adalah batas yang didekati oleh permintaan ketika pengeluaran pemasaran industri mendekati tak terhingga untuk lingkungan yang telah ditentukan. Menurut Pearce dan Robinson (2000), Potensi pasar adalah situasi penting yang paling menguntungkan dalam lingkungan perusahaan. Potensi pasar menurut Peneliti adalah suatu ukuran pasar dari suatu produk dalam kurun waktu tertentu yang mendekati permintaan dan menguntungkan. 
Gunawan (1998), Ekonomi masyarakat adalah segala kegiatan ekonomi dan upaya masyarakat untuk memenuhi kebutuhan hidupnya (basic need) yaitu sandang, pangan, papan, kesehatan dan pendidikan. Menurut Sholahuddin (2007), Ekonomi masyarakat adalah mengatur urusan harta kekayaan baik yang menyangkut kepemilikan, pengembangan maupun distribusi. Menurut Deliarnov (2009), Ekonomi masyarakat adalah sebagian kegiatan ekonomi atau usaha yang dilakukan masyarakat kebanyakan yang dengan cara swadaya mengelola sumber daya ekonomi apa saja yang dapat di usahakan. Ekonomi masyarakat menurut peneliti adalah kegiatan usaha yang di lakukan oleh masyarakat guna mendapatkan penghasilan untuk bertahan hidupdengan cara berusaha sendiri.

Priasukmana dan Mulyadin (2001), Desa Wisata merupakan suatu kawasan pedesaan yang menawarkan keseluruhan suasana yang mencerminkan keaslian pedesaan baik dari kehidupan sosial ekonomi, sosial budaya, adat istiadat, keseharian, memiliki arsitektur bangunan dan struktur tata ruang desa yang khas, atau kegiatan perekonomian yang unik dan menarik serta mempunyai potensi untuk dikembangkan berbagai komponen kepariwisataan, misalnya atraksi, akomodasi, makanan dan minuman, cinderamata, dan kebutuhan wisata lainnya. Desa Wisata, menurut wiendu dalam Erna (2019) suatu bentuk integrasi antara atraksi dan fasilitas pendukung yang disajikan dalam suatu struktur kehidupan masyarakat yang menyatu dengan tata cara dan tradisi yang berlaku.Menurut peneliti desa wisata adalah suatu kawasan pedesaan yang memiliki atraksi dari potensi yang ada dengan tujuan untuk meningkatkan kesejahteraan masyarakatnya.

\section{METODE}

Artikel ini membahas tentang Desa Wisata Lembah Dongde, Dusun Mlilir dan Dusun Pucung RW 13 Desa Gentungan. Kecamatan Mojogedang, Kabupaten Karanganyar, Jawa Tengah yang menggunakan metode penelitian kualitatif dengan melakukan observasi dan interview kepada beberapa pengurus desa wisata lembah dongde dengan tujuan untuk mengetahui analisa potensi pasar ciplukan terhadap perekonomian masyarakat di Desa Wisata Lembah Dongde. Sumber data yang digunakan adalah data primer berupa hasil observasi, pengamatan dan wawancara dengan narasumber dari para penjual yang berprofesi sebagai petani dan berjumlah sekitar 15 orang yang berjualan di pasar ciplukan dan pengurus yang bertanggung jawab di pasar ciplukan. Sedangkan Data sekunder dalam penelitian ini adalah buku-buku referensi, brosur, dan catatan-catatan yang berkaitan dengan subjek penelitian. Metode pengamatan dilakukan langsung terjun ke desa wisata Lembah dongde terhadap potensi di sekitar pasar ciplukan serta menggunakan teknik wawancara dengan cara menyiapkan daftar pertanyaan sehingga mendapat informasi langsung dari pihak yang berkaitan yaitu pengurus pasar ciplukan dan para penjual yang berjualan di pasar ciplukan. Hasil dari pengamatan, observasi dan pengamatan kemudian menarik kesimpulan dari yang diperoleh.

\section{HASIL DAN PEMBAHASAN}

Asal usul terbentuknya pasar ciplukan dan Event yang sudah diselenggarakan di Pasar Ciplukan Desa Wisata Lembah Dongde.

Penamaan Pasar Ciplukan digagas oleh ketua Tim Pelaksana Desa Wisata ibu Tri Wahyuningsih, S.E., M.M, ketika melihat banyaknya tumbuhan ciplukan yang tumbuh subur di sepanjang area persawahan Desa Wisata Lembah Dongde dan kemanfaatan tumbuhan ciplukan ini diyakini mampu memberikan efek pengobatan herbal bagi penyembuhan berbagai penyakit seperti diabetes, kolestrol, nyeri, ginjal, radikal bebas dan lain-lain. Penamaan Pasar Ciplukan memiliki nilai unik karena mudah diingat oleh masyarakat Selain dari nilai manfaat pohon ciplukan. Dengan pengharapan dengan terealisasikannya Pasar 
Ciplukan ini bisa meningkatkan perekonomian masyarakat Desa Wisata Lembah Dongde, dan mampu membawa nama Desa Wisata Lembah Dongde lebih di kenal oleh masyarakat umum.

Pasar Ciplukan pertama kali buka pada tanggal 17 Agustus 2020. Pada saat itu masyarakat Desa Wisata Lembah Dongde melakukan kegiatan upacara bendera HUTRI yang ke 75. Dengan susunan acara upacara lalu di lanjut karnaval keliling desa, dan finish di Pasar Ciplukan. Saat pertama kali buka, Pasar Ciplukan sangat ramai oleh pengunjung dan dagangan ludes terjual. Pada akhirnya warga Desa Wisata Lembah Dongde banyak yang mendaftarkan diri ke panitia Pasar Ciplukan untuk bisa berjualan di Pasar Ciplukan, Warga yang sudah berjualan juga ketagihan untuk terus berjualan di Pasar Ciplukan. Lapak di Pasar Ciplukan terbagi menjadi 2 yaitu Lapak Pokdarwis (Kelompok) dan Lapak Mandiri.

Pasar Ciplukan menyuguhkan berbagai macam makanan tradisional zaman dahulu yang diolah dari hasil bumi masyarakat setempat seperti singkong, ubi, beras organik, buah dan sayuran khas pedesaan. Jenis makanan yang dijual seperti gambleh, mie tiwul, es cendol, sate kere, pecel, rujak, jajanan pasar, karak dan masih banyak lagi jenis dan ragam makanan yang setiap minggu selalu ada inovasi menu. Selain makanan siap saji pedagang juga menjual hasil bumi yang berasal dari panen masyarakat seperti pisang, ubi, singkong, bayam, nangka, labu dan buah-buahan. Sementara kerajinan tangan yang dihasilkan oleh masyarakat berasal dari tali pet, kayu, dan bambu. Seperti tas, besek, keranjang, kukusan, gelas bambu, moge dan sepeda bambu, kapal bambu, serta permainan edukatif dari kayu.

Pasar Ciplukan memiliki konsep zaman dulu, baik makanan, pembayaran dan seragam pedagangnya. Alat pembayaran yang digunakan di Pasar Ciplukan adalah keping kayu, sebelum melakukan transaksi, pengunjung menukarkan uang rupiah terlebih dahulu dengan keping kayu. 1 keping kayu seharga Rp 2000. Harga jual di Pasar Ciplukan ini sangatlah murah karena produk yang dihasilkan berasal dari hasil kebun/ pertanian masyarakat. Selain makanan dan alat pembayaran, seragam pedagang dan Pokdarwis Pasar Ciplukan juga sangat menarik, yaitu dengan menggunakan baju khas Karanganyar. Laki-laki menggunakan baju hangcincau dan perempuan menggunakan lurik selama berjualan.

Selain menawarkan makanan, hasil bumi dan kerajinan. Di Pasar Ciplukan juga ada sepeda antik dan delman. Sepeda antik di pajang di depan Pasar Ciplukan untuk selfi, dan juga boleh untuk di pinjam oleh pengunjung. Jika memilih untuk naik delman, pengunjung hanya membayar 3 keping koin saja, dan sudah bisa berkeliling Desa Wisata Lembah Dongde. Di dalam Pasar Ciplukan juga ada beberapa spot selfi, dan area bermain untuk anak-anak. Di tengah-tengah Pasar Ciplukan terdapat Sendang, yang di beri nama Sendang ijo, yang merupakan salah satu potensi di Desa Wisata Lembah Dongde.

Keunikan Pasar Ciplukan yang berada di sekitar Sendang Ijo dan di area terbuka yang asri menjadi daya tarik tersendiri bagi wisatawan. Rata-rata pengunjung dalam satu hari berkisar 600 hingga 800 orang. Dimana pengunjung bukan hanya berasal dari wilayah kabupaten Karanganyar namun berasal dari kota lain seperti Solo, Boyolali, Semarang, Sragen, Wonogiri, bahkan di liburan yang panjang pengunjung berasal dari Jakarta, Surabaya dan kota-kota besar lainnya. Walaupun pengunjung Pasar Ciplukan dari berbagai daerah, untuk masuk ke dalam Pasar pengunjung di wajibkan menggunakan masker dan mencuci tangan serta dilakukan check suhu tubuh, di Pasar Ciplukan terdapat Satgas Covid-19 yang bertugas untuk menegur pengunjung yang bergerombol/ tidak menggunakan masker.

Pasar Ciplukan yang terletak di area Sendang Ijo, dibuka untuk umum dengan harus mematuhi protokol kesehatan dan CHSE karena masih dalam kondisi pandemic COVID-19.Pasar Ciplukan di buka di hari minggu mulai pukul 07.00 WIB sampai selesai maksimal pukul 13.00 WIB dengan hiburan live musik, itu membuat wisatawan berlama-lama di pasar ciplukan. Saat 
berbalanja di Pasar Ciplukan pengunjung di wajibkan untuk menukar uangnya dengan koin, perkoin saat ini di bandrol dengan harga dua ribu rupiah.Potensi yang ada di Pasar Ciplukan: 1) Sendang Ijo, Sendang ijo ini berada di tengah kebun, sekarang di renovasi dan di bangunlah Pasar Ciplukan. Sendang ijo yang dahulunya sudah tidak pernah di datangi oleh orang, kini sudah di hidupkan kembali bahkan untuk sumber air di Pasar Ciplukan. Konon katanya penamaan Sendang ijo, sendang ijo merupakan area terlarang bagi pengantin yang memakai busana hijau. Penamaan Sendang Ijo diperkuat dengan kondisi alamnya yang dipenuhi pepohonan yang rindang serba hijau. Sendang ijo kini sudah terawat dengan dilakukannya pembenahan di sendang, dengan dibuat rumah, yang sekarang di sebut dengan Omah Sendang Ijo. Sendang Ijo merupakan Sendang yang terletak di Dukuh Mlilir. Penamaan Sendang Ijo sendiri tak lepas dari kondisi alam dan sisi historis yang masih melekat pada masyarakat. Sendang Ijo merupakan area terlarang bagi pengantin yang memakai busana hijau. Dalam satu cerita ada sepasang pengantin yang memakai busana hijau lalu memasuki area Sendang Ijo. Pada saat itu, pengantin wanita mengalami kesurupan dan penunggu Sendang Ijo melakukan komunikasi lewat pengantin tersebut untuk memberi tahu kepada masyarakat bahwa pengantin yang memakai busana hijau pantang masuk wilayah sendang.Penamaan Sendang Ijo diperkuat dengan kondisi alamnya yang dipenuhi pepohonan yang rindang serba hijau. Di sendang ini terdapat mata air yang dulunya merupakan sumber mata air bagi masyarakat sebelum adanya pamsimas. Selain sisi historis yang masih kental. Suasana di Sendang Ijo sangat sejuk dan segar mengingat banyaknya pepohonan rindang yang tumbuh subur hingga sekarang.

Landasan Historis dan kearifan lokal tersebut dijadikan masyarakat sebagai pusat destinasi wisata dengan konsep pasar wisata jadul yang bernama Pasar Ciplukan. Penamaan Pasar Ciplukan sendiri dikarenakan di area desa masih terdapat banyak tanaman ciplukan yang sekarang sudah mulai langka. Dengan sistem transaksi berupa koin. 2) Kuliner, Kuliner yang dijual di Pasar Ciplukan adalah kuliner Khas Desa Wisata Lembah Dongde, dan semua bahan berasal dari hasil bumi masyarakat desa. Pemberdayaan Masyarakat yang diberikan oleh Peneliti membuat masyarakat memiliki antusias untuk mengembangkan bakatnya dalam hal memasak dan dijual di Pasar Ciplukan yang diharapkan bisa membantu meningkatkan perekonomian masyarakat Desa Wisata Lembah Dongde. Kuliner ini juga membuat masyarakat menjadi kompak dan rukun dengan saling melengkapi satu denag yang lain dalam hal masakan.3) Kerajinan, Pasar ciplukan juga menjual kerajinan tangan yang dikerjakan oleh masyarakat berasal dari tali pet, kayu, dan bambu. Kerajinan yang dihasilkan seperti tas, besek, keranjang, kukusan, gelas bambu, moge dan sepeda bambu, kapal bambu, serta permainan edukatif dari kayu. Kerajinan ini jual dengan harga yang sangat murah mulai dari 2 keping koin saja. kerajinan taliped dan kerajinan bambu selain di jual di Pasar Ciplukan, juga dimasukkan ke edukasi, dan pengunjung bisa ikut melihat/ mencoba mebuat kerajinan taliped dan kerajinan dari bambu. 4) Kesenian, Warga Desa Wisata Lembah Dongde banyak yang memiliki bakat kesenian seperti reog, tari, dan gamelan. Kesenian ini selalu di tampilkan di Pasar Ciplukan secara bergantian/ Rolling oleh pemuda dan pemudi asli desa wisata lembah Dongde. Pemuda dan pemudi melakukan latihan setiap sore hari di hari selasa dan di latih oleh pengurus pokdarwis. Daya tarik yang ada di pasar Ciplukan adalah 1) Spot Selfie, Spot selfi di pasar ciplukan ada bermacam-macam, yaitu: gapura pasar ciplukan, sepeda antik, photo booth, plakatplakat tulisan dari kayu, dan pohon yang ada di tengah pasar. Selain itu berfoto di tengahtengah pasar dengan background lapak pedagang pun juga sangat menarik. 2). Arena bermain anak-anak, Selain spot selfi di Pasar Ciplukan juga ada arena bermain anak-anak. Arena bermain ini di lengkapi dengan jungkat-jungkit, gazebo, dan tempat duduk. 
Jika si anak sedang bermain, orang tuanya bisa menunggu sambil duduk dan menikmati makanan yang dibeli. 3). Sepeda antik, Sepeda antik berada di atas pasar, yang merupakan milik warga Desa Wisata Lembah Dongde, sepeda antik di pajang setiap pagisiang, dan jika ada yang ingin meminjam untuk berkeliling di persilahkan tanpa membayar, dan jika untuk berfotopun juga di perkenankan. Sepeda ini kurang lebih berjumlah 7 sepeda antik. 4). Delman, Pengunjung bisa merasakan keliling Desa Wisata Lembah Dongde dengan menaiki delman, hanya dengan dikenakan tarif 3 keping koin saja. Selain bisa berkeliling Desa Wisata Lembah Dongde, pengunjung juga bisa merasakan sensasi dusun Mlilir-Pucung yang sangat bersih dan masih banyak bangunan-bangunan kuno.

Event-event yang diadakan di Pasar Ciplukan adalah Pasar Ciplukan pertama kali buka pada tanggal 17 Agustus 2020, dibukanya Pasar Ciplukan ini dijadikan media promosi untuk mengenalkan kepada masyarakat luas potensi-potensi yang menarik di Desa Wisata Lembah Dongde. dan juga sebagai tryall awal sebelum Pasar Ciplukan di kenal lebih luas oleh masyarakat, selain itu Sekaligus sebagai acuan bagi dosen dan mahasiswa AKPARTA Mandala Bhakti bersama Kelompok Sadar Wisata dalam penataan objek-objek wisata di Wisata Lembah Dongde. Pemasaran Pasar Ciplukan pun terbilang sangat cepat sampai di telinga masyarakat umum. Pertama kali Pasar Ciplukan ini buka di exposs berita oleh Gatra.com dan dimasukkan ke dalam surat kabar (koran). Tidak hanya itu, pemasarannya pun juga melalui media sosial Wisata Lembah dongde seperti instagram, facebook, youtube, dan Web resmi Wisata Lembah Dongde. Seiring berjalannya waktu, Pasar Ciplukan kini sudah dikenal oleh masyarakat umum, terlihat dari banyaknya pengunjung yang datang ke Pasar Ciplukan yang setiap minggunya berkisar 600-800an pengunjung. Pengunjung tidak hanya dari daerah Karanganyar saja, melainkan dari Sragen, Solo, Wonogiri, Boyolali, dsb. Pasar Ciplukan semenjak di kenal masyarakat umum beberapa kali kerap dihadiri oleh wartawan-wartawan salah satunya adalah wartawan dari RRI, yang melakukan wawancara di Pasar Ciplukan pada hari minggu, 22 November 2020. Selain itu Pasar Ciplukan juga dijadikan tempat untuk beberapa event resmi di daerah Karanganyar. a) Launching Desa Wisata Lembah Dongde, Launching Desa Wisata Lembah Dongde ini pada tanggal 25 Oktober 2020, dalam acara launching ini di hadiri oleh Bapak Bupati karanganyar, bapak Drs. H. Juliyatmono, MM. Bapak Pejabat kecamatan Mojogedang, dosen dan jajaran dari AKPARTA Mandala Bhakti Surakarta, dan juga tamu undangan. Selain acara launching Desa Wisata Lembah Dongde, juga di lakukannya tanda tangan MoU oleh Desa Wisata setempat. Desa Wisata yang menandatangani $\mathrm{MoU}$ tersebut ialah Hanum Agro, Watu Lintang, KWB Pakel, Sendang Bejen, dan Bukit Jati Unggul. Acara Launching ini dilaksanakan di Pasar Ciplukan dengan mempersembahkan kesenian yang ada di Desa Wisata Lembah Dongde, yaitu tari tradisional yang ditampilkan oleh 6 anak perempuan desa, Reog yang di tampilakan oleh Remaja Desa, dan Wayang yang di tampilkan oleh salah satu remaja desa yang merupakan seorang dalang. Selain itu bapak bupati dan pejabatpejabat lainnya juga mengelilingi Pasar Ciplukan dan juga membeli makanan yang dijual di Pasar Ciplukan. b). Penilaian Desa Wisata dari Kemenparekraf (Kementrian Pariwisata dan Ekonomi Kreatif), Desa Wisata Lembah Dongde masuk ke dalam finalis 20 Besar Desa Wisata Nasional. Dalam penilaian ini tim juri 2 orang yang berasal dari Kementrian Pariwisata dan Ekonomi Kreatif yaitu ibu Dr. Santi palupi.MM dan ibu Dr. Vitria Ariani, A.Par., PGDip., M.Sc. selain itu juga di hadiri oleh bapak Diruktur Deputi SDM Kemenparekraf RI, bapak wakil bupati karanganyar, bapakbapak pejabat desa mojogedang, dosen AKPARTA Mandala Bhakti Surakarta beserta jajarannya. Penilaian ini diselenggarakan pada hari Sabtu, 21 November 2020. Tim Juri berkeliling ke tol sawah, melihat upacara menanan padi. Tim 
juri beserta yang lainnya juga mengunjungi Pasar Ciplukan dan mencicipi makanan yang dijual di Pasar Ciplukan serta membeli oleholeh. Tim juri juga memberi pesan dan kesan untuk penjual yang berjualan di Pasar Ciplukan. c). Festival Telo oleh HKTI (Himpunan Karya Tani Indonesia) karanganyar, Kegiatan festival telo diselenggarakan di Pasar Ciplukan di hari minggu, 6 Desember 2020, yang dihadiri oleh H Endang Maria Astuti, Anggota DPR RI didampingi $\mathrm{H}$ Anung Marwoko, Wakil Ketua DPRD Kabupaten Karanganyar sekaligus ketua HKTI Karanganyar.Tujuan di selenggarakannya festival ini adalah sebagai wujud keprihatinan dan empati kepada petani pada saat pandemi Covid-19 yang mengalami nasib kurang baik yaitu kesulitan membeli pupuk yang dibutuhkan dan harga jual ketela(telo) yang cenderung jatuh. Festival ini juga memberikan motivasi kepada petani agar semangat dalam berkarya, sehingga petani dapat berinovasi mengolah telo menjadi produk olahan, seperti: makaroni, keripik, getuk, timusdan aneka makanan lainnya sehingga keuntungan petani meningkat. d). Festival Kambing, Festival Kambing diselanggarakan pada hari minggu, 27 Desember 2020 yang bertempat di Pasar Ciplukan. Kegiatan festival kambing ini dalam rangka memperingati hari jadi Karanganyar yang ke-103

Pengaruh Terbentuknya Pasar Ciplukan Terhadap Perekonomian Masyarakat Desa Wisata Lembah Dongde

Masyarakat Desa Wisata Lembah Dongde sekitar 50\% memiliki mata pencaharian utama di sektor pertanian yang dikelola secara individu namun ada juga usaha di sektor lain baik yang sifatnya individual maupun kelompok, misalnya: a) Peternak kambing, peternak ayam, budidaya jamur, perkebunan (buah-buahan seperti jeruk calivornia).b)Industri kerajinan misalnya kerajinan bambu, dan kerajinan tas dari taliped (setelah adanya pendampingan dari Akpar Mandala Bhakti). c) Industri makanan olahan seperti tiwul dan nasi jagung.

Berdirinya Pasar Ciplukan sangatlah berpengaruh terhadap perekonomian masyarakat Desa Wisata Lembah Dongde, setelah berdirinya pasar ciplukan, warga yang biasanya hanya mengandalkan nafkah dari suami, kini bisa mendapat penghasilan dari berjualan di Pasar Ciplukan. Para ibu-ibu pedagang Lapak Dasawisma, dari hasil berjualan selain untuk membeli kebutuhan rumah tangga juga di tabung untuk makanmakan dan untuk rekreasi sebagai tanda syukur karena mempunyai penghasilan dari jerih payahnya sendiri. Tidak hanya untuk Lapak Dasawisma, penjual-penjual dari Lapak Mandiri juga sangat bersemangat ketika berjualan terlihat dari raut muka dan semangatnya ketika menawarkan dagangannya. Biasanya pendapatan bersih setiap minggunya berkisar antara Rp100.000 sampai Rp 500.000 per lapak, yang mana uang hasil berjualan itu bisa masuk kantong sendiri untuk pedagang mandiri, dan untuk pedagang kelompok (Dasawisma), hasilnya di bagi dengan rekan 1 kelompok. Selain untuk masyarakat, adanya Pasar Ciplukan juga membawa pengaruh untuk pemasukan desa. Setiap pedagang di berlakukan dana retribusi senilai Rp 2.000 per lapak, dan di hargai $\mathrm{Rp} 1.900$ jika pedagang menukarkan uang, 100 rupiah masuk ke desa, juga dari pendapatan parkir, sepeda motor Rp 2.000 dan mobil Rp 5.000. Untuk perminggunya uang parkir terkumpul sekitar Rp 500.000-an. Uang parkir ini di gunakan untuk membeli keperluan saat Pasar Ciplukan buka, dan sisanya masuk kas pasar.

Pasar Ciplukan berkontribusi positif terhadap peningkatan penghasilan masyarakat secara langsung, manfaat yang sangat besar dapat di rasakan masyarakat berupa peningkatan penghasilan setelah adanya Pasar Ciplukan. Selain itu dengan berdirinya Pasar Ciplukan warga bisa mengalami perubahan perekonomian secara drastis yang tadinya uang hasil panen hanya cukup untuk memenuhi kebutuhan dan mensekolahkan anak, setelah adanya Pasar Ciplukan perekonomian warga menjadi terangkat bahkan bisa digunakan untuk menabung demi masa yang akan datang, serta juga terjadinya perubahan gaya hidup. Pasar Ciplukan mampu membawa nama Desa 
Wisata Lembah Dongde (WLD) ke membuat perekonomian warga Desa Wisata masyarakat umum, sehingga berhasil Lembah Dongde meningkat dengan drastis.

Tabel 4.1 Analisis kuantitatif dampak Pasar Ciplukan

\begin{tabular}{|c|c|c|c|c|}
\hline NO & Variable & $\begin{array}{c}\text { Sebelum berdiri Pasar } \\
\text { Ciplukan }\end{array}$ & $\begin{array}{c}\text { Setelah berdiri Pasar } \\
\text { Ciplukan }\end{array}$ & $\begin{array}{c}\text { Nilai } \\
\text { Dampak }\end{array}$ \\
\hline 1. & $\begin{array}{l}\text { Dampak terhadap } \\
\text { pendapatan } \\
\text { masyarakat local }\end{array}$ & $\begin{array}{l}\text { Pendapatan masyarakat dari } \\
\text { sektor pertanian }\end{array}$ & $\begin{array}{l}\text { Adanya tambahan pendapatan } \\
\text { masyarakat dari berjualan di } \\
\text { pasar Ciplukan }\end{array}$ & Baik \\
\hline 2. & $\begin{array}{l}\text { Dampak terhadap } \\
\text { kesempatan kerja }\end{array}$ & Kesempatan kerja rendah & $\begin{array}{l}\text { Munculnya peluang kerja } \\
\text { dengan berjualan di Pasar } \\
\text { Ciplukan }\end{array}$ & Baik \\
\hline 3. & $\begin{array}{l}\text { Dampak terhadap } \\
\text { perubahan sosial }\end{array}$ & $\begin{array}{l}\text { Warga Desa wisata Lembah } \\
\text { Dongde rukun dan kompak }\end{array}$ & $\begin{array}{l}\text { Warga Desa wisata Lembah } \\
\text { Dongde semakin rukun dan } \\
\text { kompak }\end{array}$ & Baik \\
\hline 4. & $\begin{array}{l}\text { Dampak terhadap } \\
\text { pekonomian warga }\end{array}$ & $\begin{array}{l}\text { Penghasilan hanya cukup untuk } \\
\text { memenuhi kebutuhan dan } \\
\text { mensekolahkan anak }\end{array}$ & $\begin{array}{l}\text { Warga sudah bisa memiliki } \\
\text { tabungan dari hasil berjualan } \\
\text { di Pasar }\end{array}$ & Baik \\
\hline 5. & $\begin{array}{l}\text { Dampak terhadap } \\
\text { pembangunan pada } \\
\text { umumnya }\end{array}$ & $\begin{array}{l}\text { Laju pembangunan fisik desa } \\
\text { lambat }\end{array}$ & $\begin{array}{l}\text { Laju pembangunan fisik desa } \\
\text { semakin cepat }\end{array}$ & Baik \\
\hline
\end{tabular}

Kelebihan dan kekurangan Pasar Ciplukan diantanya adalah pasar Ciplukan memiliki kelebihan 1) Meningkatkan perekonomian masyarakat dan desa, 2) Sebagai ladang penghasilan kedua warga selain dari sektor pertanian, 3) Makanan bervariasi dan harganya murah, 4) Merukunkan dan mengkompakkan warga Desa Wisata Lembah Dongde, khususnya untuk penjual kelompok (Dasawisma), 5) Menguatkan solidaritas dan gotong royong warga Desa Wisata lembah Dongde. 6) Pasar Ciplukan mampu membawa nama Desa Wisata Lembah Dongde ke masyarakat umum.

Tabel 4.2 Analisis SWOT Potensi Pasar Ciplukan

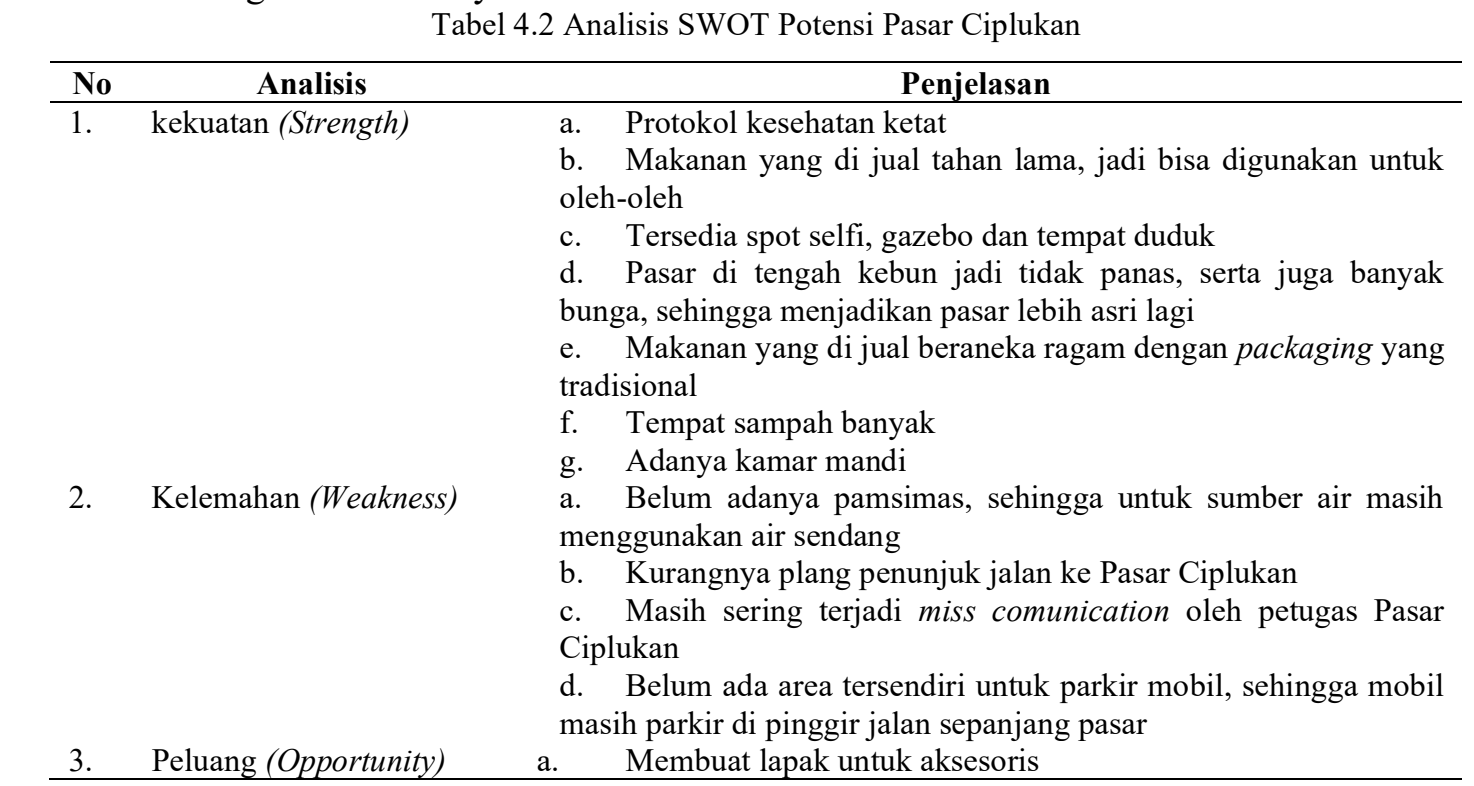

Kekurangan dari Pasar Ciplukan adalah 1) Ketika pasar ramai koin kadang sering habis, dan petugas harus mengambil dulu ke lapaklapak, 2) Kurangnya koordinasi antara panitia dan penjaga koin, sehingga jika pasar sudah buka, penjaga koin kadang belum ada, 3) Masih sering terjadi perbedaan paham saat menghitung pendapatan pasar, 4) Warga kadang masih ada yang memiliki sifat individual.5). Pengisi suara hanya menawarkan makanan yang dijual dan tol sawah (Tolsa), tidak dengan paket edukasi dan homestay. 


\begin{tabular}{ll}
\hline & b. Memberi tarif untuk pengunjung yang ingin berkeliling desa \\
menggunakan sepeda antik & \\
c. Melalukan inovasi untuk makanan yang dijual & \\
d. Selain menawarkan dagangan juga menawarkan wisata \\
edukasi dan homestay. \\
e. Selain di jual di Pasar Ciplukan, Menjual makanan dan \\
kerajinan juga dijual secara online \\
ancaman (threat) \\
dari Pasar Ciplukan baru dengan konsep yang sama yang tidak jauh \\
b. Jika tidak ada inovasi untuk rasa makanan maka pengunjung \\
akan merasa kecewa dan akan pindah tempat \\
b. Jika ada sedikit keteledoran untuk protokol kesehatan maka \\
akan berpengaruh besar \\
c. Ditakutkan terjadi longsor karna lokasi pasar yang turun ke \\
bawah \\
d. Kebersihan pasar sangat di utamakan, karena lokasi pasar \\
yang ada di pinggir sawah. \\
\end{tabular}

Rata-rata pendapatan Pasar Ciplukan per barang atau jasa tertentu. Pasar bulan mencerminakan seluruh proses yang Winardi (2002) menyatakan bahwa pendapatan adalah semua penghasilan yang diperoleh dari pihak lain sebagai tanda balas jasa yang diberikan dimana penghasilan tersebut digunakan untuk memenuhi kebutuhan keluarga atau perseorangan. Pasar adalah alat yang memungkinkan individu berinteraksi untuk membeli dan menjual digunakan untuk membeli dan menjual barang dan jasa. Pasar mengurangi biaya transaksi dari pertukaran, yaitu biaya waktu dan informasi yang perlu dipertukarkan (A. McEachem 2001: 50-51). Berikut pendapatan Pasar Ciplukan per minggu, di hitung dari awal buka tanggal 17 Agustus 2020 sampai dengan 20 Desember 2020

Tabel 4.3 Pendapatan Pasar Ciplukan Per Minggu

\begin{tabular}{|c|c|c|c|}
\hline No & Minggu Ke & Tanggal & Pendapatan Pasar \\
\hline 1. & Launching Pasar & 17 Agustus 2020 & Rp 5.487.000 \\
\hline 2. & Minggu ke 1 & 23 Agustus 2020 & Rp 6.519 .000 \\
\hline 3. & Minggu ke 2 & 30 Agustus 2020 & $\operatorname{Rp} 7.871 .500$ \\
\hline 4. & Minggu ke 3 & 6 September 2020 & Rp 8.404.000 \\
\hline 5. & Minggu ke 4 & 13 September 2020 & Rp 7.606.000 \\
\hline 6. & Minggu ke 5 & 20 september 2020 & Rp 7.480.000 \\
\hline 7. & Minggu ke 6 & 27 September 2020 & Rp 7.586.000 \\
\hline 8. & Minggu ke 7 & 4 Oktober 2020 & Rp 7.920.000 \\
\hline 9. & Minggu ke 8 & 11 Oktober 2020 & Rp 8.570.000 \\
\hline 10 . & Minggu ke 9 & 18 Oktober 2020 & $\operatorname{Rp} 6.594 .000$ \\
\hline 11. & Minggu ke 10 & 25 Oktober 2020 & Rp 6.386 .000 \\
\hline 12. & Minggu ke 11 & 1 November 2020 & Rp 8.386.000 \\
\hline 13. & Minggu ke 12 & 8 November 2020 & $\operatorname{Rp} 6.308 .000$ \\
\hline 14. & Minggu ke 13 & 15 November 2020 & Rp 8.920.000 \\
\hline 15. & Minggu ke 14 & 22 November 2020 & Rp 7.698.000 \\
\hline 16. & Minggu ke 15 & 29 November 2020 & Rp6.376.000 \\
\hline 17. & Minggu ke 16 & 6 Desember 2020 & Rp 9.295.000 \\
\hline 18. & Minggu ke 17 & 13 Desember 2020 & $\operatorname{Rp} 8.570 .000$ \\
\hline 19. & Minggu ke 18 & 20 Desember 2020 & $\operatorname{Rp} 6.606 .000$ \\
\hline 20. & Minggu ke 19 & 27 Desember 2020 & Rp 9.564.000 \\
\hline
\end{tabular}

Rata- rata adalah penghitungan dilakukan dengan menjumlahkan seluruh nilai data suatu kelompok data, kemudian dibagi dengan jumlah data tersebut. 
$\overline{\mathrm{X}}=\underline{\mathrm{x} 1+\mathrm{x} 2+\mathrm{x} 3+\ldots .+\mathrm{xn}}$

n

keterangan :

$$
\begin{aligned}
\overline{\mathrm{x}} & =\text { rata-rata hitung } \\
\mathrm{x} 1 & =\text { nilai sampel ke- } 1 \\
\mathrm{n} & =\text { jumlah sampel }
\end{aligned}
$$

Berikut rata-rata Pasar Ciplukan, di hitung per bulannya

1) Bulan Agustus 2020

$$
\begin{aligned}
& \bar{x}=\frac{x 1+x 2+x 3+\ldots .+x n}{n} \\
& =\operatorname{Rp} 5.487 .000+\operatorname{Rp} 6.519 .000 \\
& 2
\end{aligned}
$$

$=\frac{\operatorname{Rp} 12.006 .000}{2}$

$=\operatorname{Rp} 8.746 .500$

Jadi rata-rata penghasilan Pasar Ciplukan pada bulan Agustus 2020 adalah Rp 8.746.500

2) Bulan September

$$
\begin{aligned}
& \quad \overline{\mathrm{X}}=\frac{\mathrm{x} 1+\mathrm{x} 2+\mathrm{x} 3+\ldots .+\mathrm{xn}}{\mathrm{n}} \\
& =\frac{\operatorname{Rp} 8.404 .000+\mathrm{Rp} 7.606 .000+\mathrm{Rp} 7.586 .000+\mathrm{Rp} 7.480 .000}{4} \\
& =\frac{\operatorname{Rp~} 31.076 .000}{4} \\
& =\operatorname{Rp~7.769.000~}
\end{aligned}
$$

Jadi rata-rata penghasilan Pasar Ciplukan pada bulan September adalah Rp 7.769.000

3) Bulan Oktober

$$
\begin{aligned}
\bar{X} & =\frac{x 1+x 2+x 3+\ldots .+x n}{n} \\
& =\frac{\operatorname{Rp~} 7.920 .000+\operatorname{Rp~} 8.570 .000+\operatorname{Rp~} 6.594 .000+\operatorname{Rp~} 6.386 .000}{4}
\end{aligned}
$$




$$
\begin{array}{r}
=\frac{\operatorname{Rp} 29.470 .000}{4} \\
=\operatorname{Rp~} 7.367 .500
\end{array}
$$

Jadi rata-rata penghasilan Pasar Ciplukan pada bulan Oktober adalah Rp 7.367.500

4) Bulan November

$$
\begin{aligned}
& \overline{\mathrm{X}}=\mathrm{x} 1+\mathrm{x} 2+\mathrm{x} 3+\ldots .+\mathrm{xn} \\
& \text { n } \\
& =\operatorname{Rp} 8.386 .000+\operatorname{Rp} 6.308 .000+\operatorname{Rp} 8.920 .000+R p 7.698 .000 \text { Rp6.376.000 } \\
& 5 \\
& =\operatorname{Rp} 37.688 .000 \\
& 5 \\
& =\operatorname{Rp} 7.537 .000
\end{aligned}
$$

Jadi rata-rata penghasilan Pasar Ciplukan pada bulan November adalah Rp 7.537.000

5) Bulan Desember

$$
\begin{aligned}
\bar{X} & =\frac{x 1+x 2+x 3+\ldots .+x n}{n} \\
& =\frac{\operatorname{Rp} 9.295 .000+\operatorname{Rp~} 8.570 .000+\operatorname{Rp} 6.606 .000+\operatorname{Rp} 9.564 .000}{4} \\
& =\frac{\operatorname{Rp~} 34.035 .000}{4} \\
& =\operatorname{Rp~} 8.508 .750
\end{aligned}
$$

Jadi rata-rata penghasilan Pasar Ciplukan pada bulan Desember adalah Rp 8.157.000 Grafik Diagram

Berikut Grafik Diagram Pasar Ciplukan selama 5 bulan, dari mulai pertama kali buka tanggal 17 Agustus 2020 hingga 20 Desember 2020 


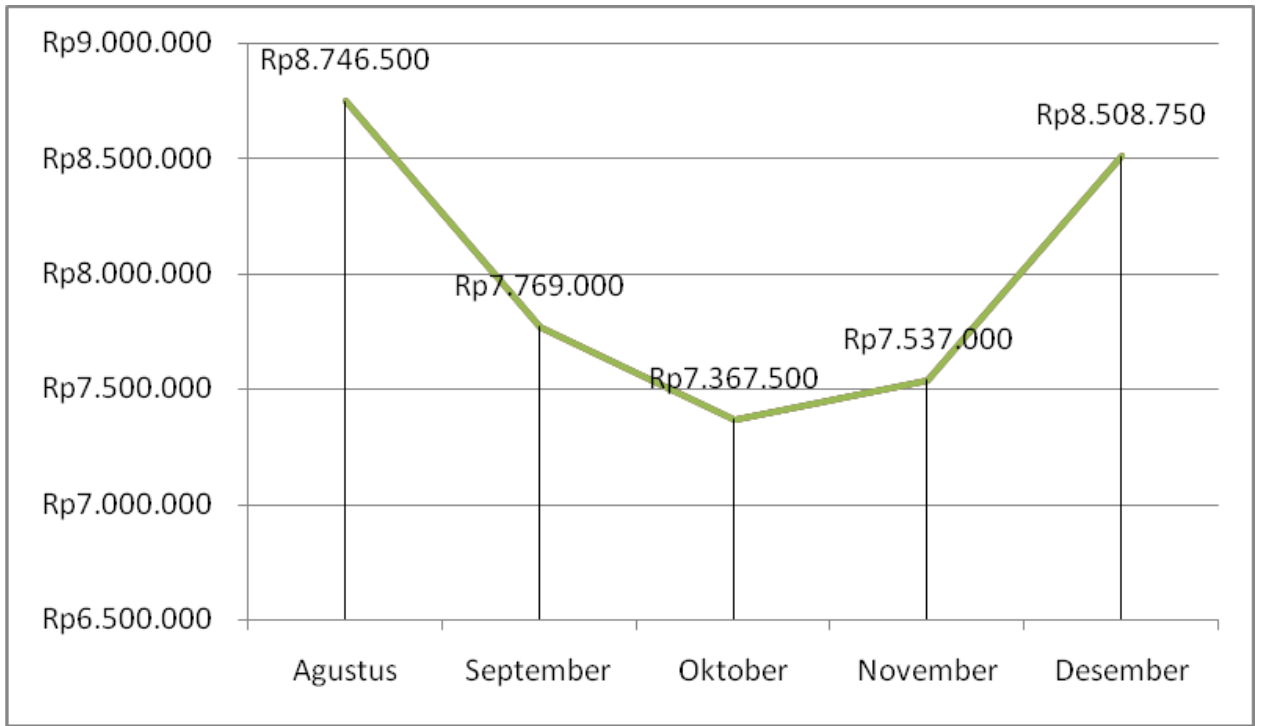

Grafik 4.1 Grafik Pendapatan Pasar Ciplukan 5 Bulan

Keterangan:

Diagram grafik Pasar Ciplukan mengalami kenaikan dan penurunan, kenaikan dialami pada bulan November dan bulan Desember, sedangkan penurunan dialami pada bulan September dan bulan Oktober.

\section{SIMPULAN}

Kesimpulan dalam artikel ini adalah Masyarakat dapat memanfaatkan lahan kosong desa dengan mendirikan Pasar Ciplukan sehingga bisa menciptakan daya tarik tersendiri untuk wisatawan berkunjung ke Desa Wisata Lembah Dongde, Masyarakat Desa Wisata Lembah Dongde merasakan perubahan perekonomian yang sangat drastis setelah adanya pendampingan oleh Akpar Mandala Bhakti Surakarta, terutama dengan adanya Pasar Ciplukan. Selain meningkatkan perekonomian masyarakat Desa Wisata Lembah Dongde, Pasar Ciplukan juga memberi pemasukan untuk kas desa, Pasar Ciplukan mampu menurunkan angka pengangguran di Desa Wisata Lembah Dongde, dengan tersedianya lapangan pekerjaan baru untuk menjual kuliner maupun kerajinan.

\section{REFERENSI}

Ashari, R. (2018). Pengembangan Pariwisata di Kabupaten Tegal. Universitas Pendidikan Indonesia.
A. McEachern, W. (2001). Pengantar Ekonomi Mikro. Jakarta. PT. Salemba Empat

Deliarnov. (2009). Perkembangan Pemikiran Ekonomi. Jakarta: Rajawali Pers

Wigati. (2019). Peran Pemberdayaan Masyarakat dalam Mengembangkan Desa Wisata di Desa Sumbberbulu Mojogedang Karanganyar. Hotelier jurnal, hospitality and tourism

Kotler, P.(1997). Manajemen Pemasaran: Edisi Bahasa indonesia Jilid satu. Jakarta: Prentice Hall

Pearce \& Robinson. (2000). Manajemen Strategi. Jakarta: Salemba Empat

Priasukmana, S \& Mulyadin, R.M. (2001). Pembangunan Desa Wisata: Pelaksanaan Undang-Undang Otonomi Daerah. Info Sosial Ekonomi, 2(1) 
Sholahuddin, M. (2007). Asas-asas Ekonomi Islam. Jakarta: PT Grafindo Persada

Sumodiningrat, G. (1998). Membangun Perekonomian Rakyat. Yogyakarta: Pustaka Pelajar

Wahab, S. (2003). Manajemen Kepariwisataan. Jakarta: Pradnya Paramitha

Winardi, (2001). Motivasi dan Pemotivasian dalam Manajemen, Cetakan Pertama. Jakarta: PT. Raja Grafindo Persada

\section{BIODATA PENULIS}

Pontianus Kuswiyata, SE.,M.Par, Email:attacos@yahoo.com.

Dosen Bidang Kajian Pariwisata di Akademi Pariwisata Mandala Bhakti, Surakarta

Erna Wigati, S.Pd.,M.Pd, Email: ernawigati16@gmail.com.

Dosen Bidang Kajian Pariwisata di Akademi Pariwisata Mandala Bhakti, Surakarta 